\title{
Allergic respiratory disease (ARD), setting forth the basics: proposals of an expert consensus report
}

\author{
Ana M. Navarro ${ }^{1 *}\left(\mathbb{0}\right.$, Julio Delgado ${ }^{2}$, Rosa M. Muñoz-Cano ${ }^{3}$, M. Teresa Dordal ${ }^{4,5}$, Antonio Valero ${ }^{3}$, \\ Santiago Quirce ${ }^{6}$ and Behalf of the ARD Study Group
}

\begin{abstract}
Background: The variability of symptoms observed in patients with respiratory allergy often hampers classification based on the criteria proposed in guidelines on rhinitis and asthma.

Objectives: We assessed specific aspects of allergic respiratory disease (ARD) that are not explicitly addressed in the guidelines in order to issue specific recommendations and thus optimize clinical practice.

Methods: Using the Delphi technique, 40 Spanish allergists were surveyed to reach consensus on 71 items related to ARD.

Results: Consensus was achieved for $95.7 \%$ of the items. These included the following: the clinical manifestations of ARD are heterogeneous and individual airborne allergens can be related to specific clinical profiles; the optimal approach in patients with ARD is based on the global assessment of rhinoconjunctivitis and asthma; aeroallergens are largely responsible for the clinical features and severity of the disease; and clinical expression is associated with the period of environmental exposure to the allergen. Pharmacological treatment of ARD is often based on the intensity of symptoms recorded during previous allergen exposures and cannot always be administered following a step-up approach, as recommended in clinical practice guidelines. Allergen immunotherapy (AIT) is the only option for overall treatment of respiratory symptoms using an etiological approach. AIT can modify the prognosis of ARD and should therefore be considered a valuable first-line treatment.
\end{abstract}

Conclusions: The present study highlights gaps in current asthma and rhinitis guidelines and addresses specific aspects of ARD, such as global assessment of both asthma and rhinitis or the specific role of variable allergen exposure in the clinical expression of the disease.

Keywords: Consensus, Delphi method, Allergic respiratory disease, One airway, Aeroallergens, Allergic asthma, Allergic rhinitis, Allergic rhinoconjunctivitis, Allergen immunotherapy

\section{Background}

Since the publication of the ARIA document in 2001 [1], the "one airway" concept has been accepted almost unanimously by the medical community to describe specific aspects of patients diagnosed with rhinoconjunctivitis with or without asthma. This concept reflects the obvious

\footnotetext{
*Correspondence: anam.navarro.sspa@juntadeandalucia.es

1 UGC of Allergy, Hospital El Tomillar , Carretera Alcalá - Dos Hermanas km

6, 41700 Dos Hermanas, Seville, Spain

Full list of author information is available at the end of the article
}

epidemiological, pathophysiological, diagnostic, and therapeutic relationship between both disorders. In fact, rhinoconjunctivitis and asthma are considered different manifestations of the same disease, and this observation determines clinical management.

It is therefore surprising that consensus guidelines do not usually consider asthma and rhinoconjunctivitis as one disease that should be managed using a comprehensive approach. Furthermore, the focus of current guidelines is mostly on the pathophysiological, clinical, and therapeutic aspects of rhinoconjunctivitis and asthma, 
with no emphasis on the etiological factors [2-10]. Nevertheless, allergens play a decisive role in the onset of symptoms and influence the clinical manifestations and progress of both rhinoconjunctivitis and allergic asthma. Current classifications of asthma and/or allergic rhinitis by consensus guidelines cannot be universally applied to patients with allergic respiratory disease owing to their high heterogeneity. Therefore, a comprehensive understanding of patients with allergic respiratory disease (ARD) requires that specific aspects of the etiological agent be addressed in the guidelines.

The present consensus defines the characteristics of ARD and reflects on the peculiarities of the disease as a single entity. This document is based on available evidence and the experience of clinical experts. It provides advice to professionals treating patients whose peculiarities are not explicitly included in guidelines and makes a series of recommendations to address this unmet need.

\section{Methods}

A scientific committee formed by the authors of this manuscript reviewed the relevant medical literature and developed a structured questionnaire to include specific aspects of ARD from routine practice that are poorly covered by current guidelines. Using a modified Delphi methodology [11], 40 expert allergists who were members of the Committees of Asthma and rhinoconjunctivitis of the Spanish Society of Allergy and Clinical Immunology (SEAIC) between 2010 and 2014 (see "Acknowledgements" section) anonymously assessed the 71 statements in 2 consecutive rounds between September and December 2014. The 71 items were divided into 4 blocks as follows: (1) Definition and Epidemiology, (2) Physiopathology and Etiology, (3) Symptoms, Classification, and Diagnosis; and (4) Treatment: Avoidance, Drug Treatment, and Allergen Immunotherapy (AIT).

After analyzing the results of the first round, one of the facilitators provided an anonymous summary of the results, as well as the reasons allergists provided for their judgements. Thus, allergists were encouraged to revise their earlier answers in light of the replies of other members of the panel, and a second round was held to address the remaining questions. A 9-point, single, ordinal, Likert-type scale was used to grade opinion on each item. Following the Delphi categorization, responses were classified into 3 groups: "disagreement" (1-3), "neither agreement nor disagreement" (4-6), and "agreement" (7-9). The survey also offered the possibility of adding individual explanatory observations for each answer. Once the second round was finished, the results were analyzed. The median position of the scores and the level of agreement or disagreement [12] achieved were measured according to the following criterion: consensus was considered to have been reached for an item when no more than a third of the scores were outside the region of three points $(1-3$, $4-6,7-9)$ from where the median was located. In this case, the value of the median score determined the group consensus reached, as follows: "agreement", majority with medians $\geq 7$; "disagreement", majority with medians $\leq 3$; "no consensus", items with medians in the region 4-6 and when the scores of a third or more of the participants were in the region $1-3$, and another third or more in the region 7-9. The items for which dispersion of opinions was high (interquartile range $\geq 4$ points) were also considered for assessment.

\section{Results}

In the literature review carried out, we found that most guidelines and position papers on rhinitis [2-6] emphasize the relationship between asthma and rhinitis (Table 1), and specific sections of some asthma guidelines discuss the relationship between asthma and rhinitis [7-10] (Table 2). However, no guidelines consider both asthma and rhinoconjunctivitis as one disease and offer a comprehensive approach.

With respect to the issues addressed in this study, consensus was achieved for $95.7 \%$ (68/71) of the items (agreement, 67; disagreement, 1) (Tables 3, 4, 5, 6). In the first round, consensus was achieved in all but 7. Among the items for which consensus was achieved, it is especially interesting that experts consider that individual aeroallergens may be related to specific clinical profiles and should be taken into account for patient management. In addition, pharmacological treatment of ARD in routine practice is often based on the intensity of symptoms during previous exposures and may not always be established using a step-up approach, as recommended by clinical practice guidelines. As for AIT, the experts think that this approach can modify the prognosis of ARD and should therefore be considered a valuable firstline treatment. No agreement was reached for item 46 ("Patients with ARD sensitized to pollens present symptoms only during the pollen season").

Consensus was not reached on 3 items in the diagnosis and treatment blocks, as follows: "The diagnosis of ARD with lower respiratory tract involvement can be assumed in patients with allergic rhinoconjunctivitis and symptoms of bronchial asthma (even if asthma has not been confirmed by lung function tests)" (item 48); "The doses used in the pharmacological treatment of ARD patients may be greater than those commonly used in non-allergic patients" (item 59); and "AIT decreases the occurrence of new sensitizations in ARD patients" (item 67).

Detailed results for each item (mean, median, percentage of distribution of respondents located outside the 
Table 1 Asthma in guidelines on rhinitis

\begin{tabular}{|c|c|c|c|}
\hline Guideline & $\begin{array}{l}\text { Author, } \\
\text { year }\end{array}$ & Chapter & Diagnostic or therapeutic considerations \\
\hline $\begin{array}{l}\text { Clinical practice guideline: allergic rhinitis } \\
\text { [6] }\end{array}$ & $\begin{array}{l}\text { Seidman, } \\
2015\end{array}$ & $\begin{array}{l}\text { Statement 5. Chronic Condi- } \\
\text { tions and Comorbidities: } \\
\text { Clinicians should assess } \\
\text { patients with a clinical diag- } \\
\text { nosis of allergic rhinitis for, } \\
\text { and document in the medi- } \\
\text { cal record, the presence } \\
\text { of associated conditions } \\
\text { such as asthma, atopic der- } \\
\text { matitis, sleep-disordered } \\
\text { breathing, conjunctivitis, } \\
\text { rhinosinusitis, and otitis } \\
\text { media }\end{array}$ & $\begin{array}{l}\text { Evaluation of allergic rhinitis must always include the } \\
\text { assessment of asthma. The clinician should inquire about } \\
\text { typical symptoms such as dyspnea, cough, wheezing, and } \\
\text { exercise-related symptoms. A physical examination should } \\
\text { be performed, and the evaluation must be repeated at the } \\
\text { follow-up visits, particularly in children. Spirometry must } \\
\text { be performed whenever asthma is suspected }\end{array}$ \\
\hline $\begin{array}{l}\text { Allergic Rhinitis and its Impact on Asthma } \\
\text { (ARIA) guidelines: } 2010 \text { Revision [5] }\end{array}$ & Brozek, 2010 & $\begin{array}{l}\text { VI. Treatment of allergic } \\
\text { rhinitis and asthma in the } \\
\text { same patient }\end{array}$ & $\begin{array}{l}\text { Recommendations about medical treatment and immu- } \\
\text { notherapy: subcutaneous immunotherapy (SCIT) and } \\
\text { sublingual immunotherapy (SLIT) }\end{array}$ \\
\hline $\begin{array}{l}\text { The diagnosis and management of rhinitis. } \\
\text { An updated practice parameter [4] }\end{array}$ & $\begin{array}{l}\text { Wallace, } \\
2008\end{array}$ & $\begin{array}{l}\text { Major comorbid conditions } \\
\text { Asthma }\end{array}$ & $\begin{array}{l}\text { Lung function tests must be considered in patients with } \\
\text { rhinitis } \\
\text { Treatment of allergic rhinitis may improve asthma control in } \\
\text { patients with coexisting allergic rhinitis and asthma } \\
\text { Treatment of allergic rhinitis with intranasal corticoster- } \\
\text { oids and certain second-generation antihistamines may } \\
\text { improve asthma control when both diseases coexist } \\
\text { Allergen immunotherapy may prevent the development } \\
\text { of new allergen sensitizations and reduce the risk for the } \\
\text { future development of asthma in patients with allergic } \\
\text { rhinitis }\end{array}$ \\
\hline $\begin{array}{l}\text { BSACI (British Society for Allergy and } \\
\text { Clinical Immunology) guidelines for the } \\
\text { management of allergic and non-allergic } \\
\text { rhinitis [3] }\end{array}$ & $\begin{array}{l}\text { Scadding, } \\
2008\end{array}$ & $\begin{array}{l}\text { Co-morbid association } \\
\text { Rhinitis and asthma-the link }\end{array}$ & $\begin{array}{l}\text { Treatment of rhinitis is associated with improvement of } \\
\text { asthma (Grade of recommendation, } A \text { ) } \\
\text { Patients with comorbid asthma and rhinitis receiving treat- } \\
\text { ment for allergic rhinitis have a significantly lower risk of } \\
\text { hospitalization or emergency department visits for asthma }\end{array}$ \\
\hline $\begin{array}{l}\text { Allergic Rhinitis and its Impact on Asthma } \\
\text { (ARIA) } 2008 \text { Update [2] }\end{array}$ & $\begin{array}{l}\text { Bousquet, } \\
2008\end{array}$ & $\begin{array}{l}\text { 9. Link between rhinitis and } \\
\text { asthma }\end{array}$ & $\begin{array}{l}\text { Allergic rhinitis should be considered a risk factor for asthma } \\
\text { along with other known risk factors } \\
\text { Patients with persistent allergic rhinitis must be evaluated } \\
\text { for asthma based on symptoms, physical examination, } \\
\text { and, if possible lung function tests (spirometry pre- and } \\
\text { post-bronchodilator). Patients with asthma must be appro- } \\
\text { priately evaluated (history and physical examination) for } \\
\text { rhinitis } \\
\text { A combined strategy for the treatment of both upper and } \\
\text { lower airway diseases is strongly recommended }\end{array}$ \\
\hline
\end{tabular}

region of the median, interquartile range, and consensus result) are shown in Tables 3, 4, 5 and 6.

\section{Discussion}

The "one airway, one disease" concept [13] has successfully taken root in the medical community, although it is far from being a reality in clinical practice. In fact, there are currently no consensus guidelines for ARD patients. Thus, management is not based on homogeneous criteria and requires the use of 2 separate guidelines, 1 for asthma and 1 for rhinoconjunctivitis.

This consensus study aimed to collect expert opinions from Spanish allergologists about the symptoms, classification, diagnosis, and treatment of ARD to provide a comprehensive approach for clinical practice. A major goal was to address the importance of the allergen as the modulator of individual variability in clinical expression based on the duration and intensity of exposure.

\section{ARD: Definition}

Given the publication of the ARIA guidelines in 2001 [1], the panel agreed that "there is abundant evidence confirming the notion of one airway, one disease as the conceptual basis of the management of patients diagnosed with rhinoconjunctivitis and/or asthma" (item 1). Therefore, it follows that "the definition of ARD as a single entity that includes rhinoconjunctivitis and asthma would facilitate its management" (item 2), especially when allergy is its main cause. Finally, the experts of this consensus agreed on the definition that "ARD is 
Table 2 Rhinitis in asthma: guidelines

\begin{tabular}{|c|c|c|c|}
\hline Guideline & Author, year & Chapter & Diagnostic or therapeutic considerations \\
\hline $\begin{array}{l}\text { GEMA } 4.0 \text { [7], Spanish Guideline } \\
\text { on the Management of Asthma }\end{array}$ & $\begin{array}{l}\text { Executive Committee of } \\
\text { the GEMA, } 2015\end{array}$ & 6. Rhinitis and nasal polyposis & $\begin{array}{l}\text { Treatment of rhinitis is indicated in the treatment } \\
\text { of asthma } \\
\text { Inter-relationships between treatments (anti-leukot- } \\
\text { rienes, intranasal corticosteroids, immunotherapy) } \\
\text { and epidemiological aspects are addressed }\end{array}$ \\
\hline $\begin{array}{l}\text { GINA 2016, Global Strategy for } \\
\text { Asthma Management and } \\
\text { Prevention [8] }\end{array}$ & 2016 GINA Report & $\begin{array}{l}\text { Part D. Managing asthma with } \\
\text { comorbidities and in special } \\
\text { populations } \\
\text { Rhinitis, sinusitis and nasal polyps }\end{array}$ & Refers to ARIA \\
\hline $\begin{array}{l}\text { British guideline on the Manage- } \\
\text { ment of Asthma [9] }\end{array}$ & $\begin{array}{l}\text { British Thoracic Society, } \\
2014\end{array}$ & No & $\begin{array}{l}\text { Studies confirm that atopic dermatitis and atopic } \\
\text { rhinitis are amongst the factors most strongly } \\
\text { associated with asthma persisting into teenage } \\
\text { years }\end{array}$ \\
\hline $\begin{array}{l}\text { NAEPP [10], National Asthma Edu- } \\
\text { cation and Prevention Program }\end{array}$ & $\begin{array}{l}\text { Expert Panel Report 3, } \\
2007\end{array}$ & $\begin{array}{l}\text { Section 3, Component 3: Control } \\
\text { of Environmental Factors and } \\
\text { Comorbid Conditions That } \\
\text { Affect Asthma } \\
\text { Comorbid conditions } \\
\text { Rhinitis/sinusitis }\end{array}$ & $\begin{array}{l}\text { It is important for clinicians to appreciate the } \\
\text { association between upper and lower airway } \\
\text { conditions and the part this association plays in } \\
\text { asthma management }\end{array}$ \\
\hline
\end{tabular}

an altered state of health caused by the generation of $\operatorname{IgE}$ antibodies to airborne allergens leading to various clinical manifestations in the upper and/or lower airway" (item 3).

Allergic inflammation is present in both the upper airway and the lower airway $[14,15]$, although it may be of locally different intensity (items $4,17,18$ ). Therefore, a unified assessment of the airway is necessary, irrespective of whether symptoms of both asthma and rhinoconjunctivitis are present at a given time in a patient (item 9).

The concept of ARD is based on the allergic origin of the disease, and its clinical spectrum includes conjunctivitis, rhinitis, and/or asthma. Not all clinical manifestations must occur simultaneously in ARD patients, although the risk of developing the other clinical manifestations of ARD in the future is greater than in the general population [16].

\section{The allergen as a key factor in ARD}

In ARD patients, allergens and clinical exacerbations are the main triggers of inflammation (acute and chronic). The ARD consensus highlights the importance of considering allergic sensitization in diagnostic and therapeutic decisions.

Various airborne allergens can induce a variety of respiratory symptoms with a wide spectrum of severity [17]. Furthermore, sensitization to several agents (polysensitization) can also substantially modify the clinical features and prognosis of ARD patients [18]. As shown by several studies, specific allergens more frequently induce symptoms in the upper respiratory tract than in the lower respiratory tract (item 27) [19]. In addition, some airborne allergens are related to the most severe forms of asthma (item 28) [20] or persistent forms of asthma [21], and some allergens can lead to worse quality of life than others owing to the characteristics of their exposure (item 29) [22]. Age at sensitization and allergen involved have even been linked to the appearance of specific symptoms [23]. Sensitization to certain allergens, for instance Alternaria species, has also been noted as a risk factor for exacerbations [24], severe exacerbations, and even death from asthma [25]. Furthermore, recent studies have linked specific allergens to various late reactions in asthma: whereas house dust mites induce more severe late reactions than pollens, animal dander allergens are related to reactions of intermediate intensity [26].

Other factors modulate the clinical response to the allergen. These include "allergenic pressure", which is the combination of both intensity and duration of exposure to an airborne allergen. The experts agreed that "a patient with ARD can manifest allergic rhinoconjunctivitis after being exposed to a specific allergen and asthma after exposure to a different one" (item 32) and "in the same patient, the presence of rhinoconjunctivitis and/or asthma at a particular time may depend on the intensity and duration of exposure to the allergen" (item 33).

For the experts consulted, unlike non-allergic asthma or rhinitis, "control of ARD varies significantly depending on the intensity of exposure to the responsible allergen" (item 41).

Contact with an allergen causes pathophysiological changes that affect the development of symptoms triggered not only by allergens, but also by other agents, such as infectious microorganisms (item 23). These symptoms are more intense when patients are exposed to both an allergen and an infectious agent [27]. Recent studies have 
Table 3 Items included in the questionnaire and results

\begin{tabular}{|c|c|c|c|c|c|c|}
\hline & & Mean & Median & $\begin{array}{l}\text { Interquartile } \\
\text { range }\end{array}$ & $\begin{array}{l}\text { Above the } \\
\text { median }\end{array}$ & Result \\
\hline 1 & $\begin{array}{l}\text { There is abundant evidence confirming the notion of one airway, one } \\
\text { disease, which is the conceptual basis of the management of patients } \\
\text { diagnosed with rhinoconjunctivitis and/or asthma }\end{array}$ & 8.13 & 8 & 1 & 10 & Agreement \\
\hline 2 & $\begin{array}{l}\text { The definition of allergic respiratory disease (ARD) as a single entity } \\
\text { that includes rhinoconjunctivitis and asthma would facilitate its } \\
\text { management }\end{array}$ & 7.38 & 8 & 2.5 & 25 & Agreement \\
\hline 3 & $\begin{array}{l}\text { ARD is an altered state of health caused by the generation of lgE anti- } \\
\text { bodies to airborne allergens leading to various clinical manifestations } \\
\text { in the upper and/or lower airway }\end{array}$ & 7.85 & 8 & 2 & 10 & Agreement \\
\hline 4 & $\begin{array}{l}\text { The ARD endotype is characterized by the presence of allergic airway } \\
\text { inflammation that constitutes the etiological basis of the disease and } \\
\text { its exacerbations }\end{array}$ & 7.98 & 8.5 & 1.5 & 12.5 & Agreement \\
\hline 5 & $\begin{array}{l}\text { The clinical manifestations of ARD include nasal (or naso-ocular) symp- } \\
\text { toms and/or bronchial symptoms }\end{array}$ & 8.55 & 9 & 1 & 0 & Agreement \\
\hline 6 & $\begin{array}{l}\text { The clinical manifestations of ARD may be present perennially or } \\
\text { seasonally }\end{array}$ & 8.08 & 9 & 1 & 15 & Agreement \\
\hline 7 & $\begin{array}{l}\text { The clinical manifestations of ARD may be present intermittently or } \\
\text { persistently }\end{array}$ & 8.3 & 9 & 1 & 7.5 & Agreement \\
\hline 8 & $\begin{array}{l}\text { The clinical manifestations of ARD may be variable at different times in } \\
\text { the patient's life }\end{array}$ & 8.55 & 9 & 1 & 0 & Agreement \\
\hline 9 & $\begin{array}{l}\text { A comprehensive approach to rhinoconjunctivitis and allergic asthma } \\
\text { includes the assessment of both entities, irrespective of whether } \\
\text { they are present at a given time in a patient }\end{array}$ & 8.15 & 9 & 1 & 7.5 & Agreement \\
\hline 10 & The prevalence of ARD depends on the age of the patient & 7.93 & 8 & 2 & 7.5 & Agreement \\
\hline 11 & $\begin{array}{l}\text { The prevalence of ARD depends on the clinical manifestations ana- } \\
\text { lyzed (rhinoconjunctivitis, asthma, or both) }\end{array}$ & 7.6 & 8 & 2 & 12.5 & Agreement \\
\hline 12 & The prevalence of ARD has geographic variability. & 7.43 & 8 & 2 & 20 & Agreement \\
\hline 13 & Allergic rhinitis usually precedes the development of asthma in adults & 7.7 & 8 & 1 & 7.5 & Agreement \\
\hline 14 & $\begin{array}{l}\text { The probability of developing symptoms affecting the lower airway } \\
\text { is increased by up to 3-5 times in patients with ARD expressed as } \\
\text { persistent allergic rhinitis }\end{array}$ & 7.83 & 8 & 1.5 & 5 & Agreement \\
\hline 15 & $\begin{array}{l}\text { Rhinoconjunctivitis and asthma may appear consecutively or simulta- } \\
\text { neously in ARD patients }\end{array}$ & 8.3 & 8 & 1 & 0 & Agreement \\
\hline 16 & $\begin{array}{l}\text { An early assessment of ARD should be in made children with food } \\
\text { allergy and/or atopic dermatitis }\end{array}$ & 8 & 8 & 1 & 7.5 & Agreement \\
\hline
\end{tabular}

Definition and Epidemiology

linked the persistence of asthma after removing the allergenic trigger in individuals with ARD with the activation of Th2-mediated myeloid dendritic cells [28]. The experts agreed that the allergic nature/substrate of ARD might also influence the persistence of respiratory symptoms during periods of no exposure to an allergen (item 46).

\section{Specific aspects of the diagnosis of ARD}

The expert panel agreed that control of ARD depends on a comprehensive diagnosis, including identification of the causative allergen/s and its/their clinical relevance (item 41).

It is well known that "patients with ARD may not meet functional and inflammatory criteria for rhinitis and/or asthma when allergen exposure is not present" (item 47), as occurs in individuals sensitized to pollens out of season [29].
Allergen exposure can influence the results of the diagnostic tests most commonly used in rhinoconjunctivitis and asthma. Whereas allergy tests (skin prick test, specific IgE, allergen challenge) are still useful when patients have no symptoms (item 49), lung function tests may fail to detect bronchial involvement (item 50). Thus, the diagnosis of allergic rhinitis can be made independently of the allergenic exposure. However, according to guidelines, diagnosis of asthma requires the objective demonstration of lower respiratory tract involvement (reversible obstruction, hyperresponsiveness) [7].

\section{Specific aspects of treatment of ARD: drug therapy}

The expert panel agreed that the therapeutic and diagnostic approach to ARD patients cannot be solely and strictly based on the recommendations of current guidelines. Adjustment of drugs and doses is based on the 
Table 4 Items included in the questionnaire and results

\begin{tabular}{|c|c|c|c|c|c|c|}
\hline & & Mean & Median & $\begin{array}{l}\text { Interquartile } \\
\text { range }\end{array}$ & $\begin{array}{l}\text { Above the } \\
\text { median }\end{array}$ & Result \\
\hline 17 & $\begin{array}{l}\text { ARD is characterized as an inflammatory process with a characteristic } \\
\text { Th2-mediated response profile }\end{array}$ & 8.08 & 8 & 1.5 & 5 & Agreement \\
\hline 18 & $\begin{array}{l}\text { ARD is characterized by inflammation of both the upper and the lower } \\
\text { respiratory tract, which may be of different intensity }\end{array}$ & 8.35 & 8.5 & 1 & 0 & Agreement \\
\hline 19 & $\begin{array}{l}\text { Bronchial hyperresponsiveness is observed in more than one-third of } \\
\text { ARD patients who have clinical manifestations in the upper airway }\end{array}$ & 8.13 & 8 & 1 & 2.5 & Agreement \\
\hline 20 & $\begin{array}{l}\text { Although no single mechanism fully explains rhinitis-asthma inter- } \\
\text { relationships, systemic spread of allergic inflammatory mediators is } \\
\text { the most widely accepted pathway }\end{array}$ & 6.55 & 7 & 1 & 30 & Agreement \\
\hline 21 & $\begin{array}{l}\text { Functional impairment of the bronchial epithelium leads to increased } \\
\text { susceptibility to infections and facilitates new allergic sensitizations } \\
\text { in ARD patients }\end{array}$ & 7.45 & 8 & 2 & 17.5 & Agreement \\
\hline 22 & $\begin{array}{l}\text { The underlying pathophysiological changes are present all year long in } \\
\text { ARD patients with only seasonal clinical manifestations, as a result of } \\
\text { infections or exposure to environmental irritants }\end{array}$ & 7.5 & 8 & 1 & 20 & Agreement \\
\hline 23 & $\begin{array}{l}\text { Respiratory infections are usually more severe and last longer in ARD } \\
\text { patients }\end{array}$ & 7.05 & 8 & 1 & 22.5 & Agreement \\
\hline 24 & $\begin{array}{l}\text { Clinical manifestations are determined mainly by environmental factors } \\
\text { but also by genetic factors }\end{array}$ & 6.7 & 7 & 3 & 30 & Agreement \\
\hline 25 & $\begin{array}{l}\text { The presence and persistence of allergens account for the characteris- } \\
\text { tics of clinical manifestations in ARD patients }\end{array}$ & 7.15 & 7 & 1 & 22.5 & Agreement \\
\hline 26 & $\begin{array}{l}\text { Allergen characteristics and type of exposure can partially determine } \\
\text { whether rhinoconjunctivitis precedes asthma or both entities } \\
\text { develop simultaneously }\end{array}$ & 7.1 & 7 & 1 & 17.5 & Agreement \\
\hline 27 & $\begin{array}{l}\text { Some allergens induce symptoms more frequently in the upper airway } \\
\text { than in the lower airway }\end{array}$ & 7.5 & 8 & 2 & 17.5 & Agreement \\
\hline 28 & Some airborne allergens are related to more severe forms of asthma & 7.98 & 8.5 & 2 & 12.5 & Agreement \\
\hline 29 & $\begin{array}{l}\text { In ARD patients, some allergens can cause worse quality of life than } \\
\text { others owing to the characteristics of their exposure }\end{array}$ & 7.85 & 8 & 2 & 10 & Agreement \\
\hline
\end{tabular}

Pathophysiology and Etiology

severity of symptoms in previous allergen exposures and does not follow the frequently recommended "step-up" strategy (item 58), especially in patients with seasonal manifestations.

Although a personalized treatment plan is recommended, we may use the "maximum severity of symptoms recorded in previous exposures" as a guide to establishing future treatments (item 57). This must be registered in the medical history (Items 34 and 35) and is particularly important if therapeutic recommendations are given when patients are not exposed to the allergens.

In the opinion of the expert panel, unlike non-allergic rhinitis and asthma, maintenance therapy may only be administered to ARD patients during allergen exposure (item 55) [9]. However, maintenance therapy may also be used over longer periods to ensure good control (item 56).

\section{Specific aspects of treatment of ARD: AIT}

As suggested previously [30], there is a common underlying pathogenic mechanism in all patients with ARD, despite differences in clinical manifestations and types of allergic sensitization. Identification of the causative allergen and prescription of an allergen-oriented treatment improve disease control and prognosis, irrespective of whether asthma and rhinoconjunctivitis appear simultaneously or sequentially. Allergen immunotherapy (AIT) is an etiology-based treatment and should be considered a firstline option in ARD based on the clinical relevance of allergen sensitization, in which exposure to an allergen elicits allergic symptoms with significant intensity or duration.

However, contrary to published evidence [31] and the opinion of the expert panel, some guidelines $[8,9]$ do not consider AIT to be first-line treatment. The experts agreed that "failure of drug therapy is not a prerequisite for AIT in patients with ARD" (item 62), and that "most of these patients will benefit from treatment with AIT to slow disease progression" (item 64). This consensus advocates for early indication of AIT under the premise that immunotherapy is most effective in the early stages of ARD (item 63) when the optimal dose is applied, thus combining efficacy and safety. 
Table 5 Items included in the questionnaire and results

\begin{tabular}{|c|c|c|c|c|c|c|}
\hline & & Mean & Median & $\begin{array}{l}\text { Interquartile } \\
\text { range }\end{array}$ & $\begin{array}{l}\text { Above the } \\
\text { median }\end{array}$ & Result \\
\hline 30 & $\begin{array}{l}\text { Ocular itching and sneezing (upper respiratory tract) and recurrent } \\
\text { wheezing (lower respiratory tract) are the symptoms that best } \\
\text { correlate with the diagnosis of ARD }\end{array}$ & 7.33 & 7 & 2 & 25 & Agreement \\
\hline 31 & $\begin{array}{l}\text { The presence of asthma must be evaluated in all patients with } \\
\text { allergic rhinoconjunctivitis }\end{array}$ & 8.58 & 9 & 1 & 2.5 & Agreement \\
\hline 32 & $\begin{array}{l}\text { A patient with ARD can manifest allergic rhinoconjunctivitis after } \\
\text { being exposed to a specific allergen and asthma after exposure to } \\
\text { a different one }\end{array}$ & 7.88 & 8 & 1.5 & 12.5 & Agreement \\
\hline 33 & $\begin{array}{l}\text { In the same patient, the presence of rhinoconjunctivitis and/or } \\
\text { asthma at a particular time may depend on the intensity and dura- } \\
\text { tion of exposure to the allergen }\end{array}$ & 8.2 & 8 & 1 & 0 & Agreement \\
\hline 34 & $\begin{array}{l}\text { We define the concept of "maximum severity" as the highest inten- } \\
\text { sity of symptoms achieved in previous allergen exposures }\end{array}$ & 7.4 & 7.5 & 1 & 17.5 & Agreement \\
\hline 35 & $\begin{array}{l}\text { Due to the variability of symptoms in ARD patients, it is important } \\
\text { to record the "most severe" episodes as well as the symptom-free } \\
\text { periods }\end{array}$ & 7.98 & 8 & 1.5 & 10 & Agreement \\
\hline 36 & $\begin{array}{l}\text { The variability of symptoms in ARD patients hampers their classifica- } \\
\text { tion using the criteria proposed by consensus guidelines }\end{array}$ & 7.85 & 8 & 2 & 12.5 & Agreement \\
\hline 37 & $\begin{array}{l}\text { The current classification used by guidelines is based on the assess- } \\
\text { ment of the intensity and frequency of symptoms of rhinocon- } \\
\text { junctivitis and asthma separately and does not assess specific } \\
\text { aspects of the causative allergens }\end{array}$ & 8.18 & 8 & 1 & 10 & Agreement \\
\hline 38 & $\begin{array}{l}\text { Besides the intensity and duration, the description of ARD symp- } \\
\text { toms should consider other aspects such as the frequency of the } \\
\text { episodes, seasonality, and recurrence of symptoms at specific } \\
\text { times }\end{array}$ & 8.35 & 8.5 & 1 & 0 & Agreement \\
\hline 39 & $\begin{array}{l}\text { A specific classification emphasizing the role of the causative aller- } \\
\text { gen is required for patients with ARD }\end{array}$ & 7.55 & 8 & 2 & 12.5 & Agreement \\
\hline 40 & $\begin{array}{l}\text { A classification considering severity, control level, and clinical } \\
\text { characteristics of the airborne allergens is required for diagnosis of } \\
\text { ARD and treatment }\end{array}$ & 7.63 & 8 & 2 & 12.5 & Agreement \\
\hline 41 & $\begin{array}{l}\text { Control of ARD varies significantly depending on the intensity of the } \\
\text { exposure to the responsible allergen }\end{array}$ & 8.08 & 8 & 1 & 5 & Agreement \\
\hline 42 & $\begin{array}{l}\text { ARD must be suspected on the basis of a compatible history and } \\
\text { allergy workup }\end{array}$ & 8.43 & 9 & 1 & 2.5 & Agreement \\
\hline 43 & $\begin{array}{l}\text { Diagnosis of ARD is based on compatible clinical manifestations, the } \\
\text { allergological study, and environmental exposure }\end{array}$ & 8.35 & 9 & 1 & 2.5 & Agreement \\
\hline 44 & $\begin{array}{l}\text { An allergological study must be indicated when symptoms of ARD } \\
\text { have an impact on a patient's quality of life }\end{array}$ & 7.03 & 8 & 2 & 22.5 & Agreement \\
\hline 45 & $\begin{array}{l}\text { Precise information regarding the characteristics of a pollen seasons } \\
\text { is required for a proper diagnosis }\end{array}$ & 8.23 & 8 & 1 & 5 & Agreement \\
\hline 46 & $\begin{array}{l}\text { Patients with ARD sensitized to pollens present symptoms only dur- } \\
\text { ing the pollen season }\end{array}$ & 3.08 & 3 & 1 & 17.5 & Disagreement \\
\hline 47 & $\begin{array}{l}\text { Patients with ARD may not meet functional and inflammatory } \\
\text { criteria for rhinitis and/or asthma when allergen exposure is not } \\
\text { present }\end{array}$ & 7.93 & 8 & 2 & 2.5 & Agreement \\
\hline 48 & $\begin{array}{l}\text { The diagnosis of ARD with lower respiratory tract involvement can } \\
\text { be assumed in patients with allergic rhinoconjunctivitis and symp- } \\
\text { toms of bronchial asthma (even if asthma has not been confirmed } \\
\text { by lung function tests) }\end{array}$ & 5.63 & 7 & 4 & 42.5 & No consensus \\
\hline 49 & $\begin{array}{l}\text { Allergy tests (prick tests, specific lgE, specific challenge) are reliable } \\
\text { both in and out of the pollen season }\end{array}$ & 8.55 & 9 & 1 & 0 & Agreement \\
\hline 50 & $\begin{array}{l}\text { Lung function tests may be normal out of the pollen season in } \\
\text { patients with upper and lower ARD during the pollen season }\end{array}$ & 7.73 & 8 & 2 & 10 & Agreement \\
\hline
\end{tabular}


Table 6 Items included in the questionnaire and results

\begin{tabular}{|c|c|c|c|c|c|c|}
\hline & & Mean & Median & $\begin{array}{l}\text { Interquartile } \\
\text { range }\end{array}$ & $\begin{array}{l}\text { Above the } \\
\text { median }\end{array}$ & Result \\
\hline 51 & $\begin{array}{l}\text { Treatment of rhinitis in patients with asthma contributes to the } \\
\text { improvement of bronchial symptoms }\end{array}$ & 7.7 & 8 & 2 & 7.5 & Agreement \\
\hline 52 & $\begin{array}{l}\text { Treatment of rhinitis in patients with asthma reduces socio-eco- } \\
\text { nomic costs }\end{array}$ & 7.93 & 8 & 1.5 & 12.5 & Agreement \\
\hline 53 & $\begin{array}{l}\text { Treatment of rhinitis in patients with asthma improves their quality } \\
\text { of life }\end{array}$ & 8.33 & 8.5 & 1 & 2.5 & Agreement \\
\hline 54 & $\begin{array}{l}\text { Allergen avoidance in ARD is the first line of treatment for all } \\
\text { patients, regardless of severity }\end{array}$ & 7.8 & 8 & 2 & 12.5 & Agreement \\
\hline 55 & $\begin{array}{l}\text { Maintenance drug therapy must be recommended, at least as long } \\
\text { as the patient is exposed to the causative airborne allergen }\end{array}$ & 7.35 & 8 & 2 & 22.5 & Agreement \\
\hline 56 & $\begin{array}{l}\text { Maintenance drug therapy can be extended for as long as is neces- } \\
\text { sary to achieve good control of the disease }\end{array}$ & 8.38 & 9 & 1 & 0 & Agreement \\
\hline 57 & $\begin{array}{l}\text { Adjustment of treatment in ARD patients must consider the "maxi- } \\
\text { mum severity reached in previous allergenic exposures" }\end{array}$ & 7.28 & 8 & 1 & 15 & Agreement \\
\hline 58 & $\begin{array}{l}\text { Treatment of patients who experienced severe symptoms in previ- } \\
\text { ous allergenic exposures may not follow the step-up strategy } \\
\text { recommended by consensus guidelines and can begin with a } \\
\text { higher therapeutic step }\end{array}$ & 7.85 & 8 & 2 & 7.5 & Agreement \\
\hline 59 & $\begin{array}{l}\text { The doses used in the pharmacological treatment of ARD patients } \\
\text { may be greater than those commonly used in non-allergic patients }\end{array}$ & 6.23 & 7 & 3 & 42.5 & No consensus \\
\hline 60 & The prognosis of ARD depends on the presence of polysensitization & 6.6 & 7 & 2 & 30 & Agreement \\
\hline 61 & $\begin{array}{l}\text { The treatment strategy in polysensitized patients consists of adapt- } \\
\text { ing maintenance treatment to the relevant allergen }\end{array}$ & 6.95 & 7 & 1 & 22.5 & Agreement \\
\hline 62 & $\begin{array}{l}\text { Failure of drug therapy is not a prerequisite for AIT in patients with } \\
\text { ARD }\end{array}$ & 8.35 & 9 & 1 & 2.5 & Agreement \\
\hline 63 & AIT is most effective in early stages of ARD & 7.95 & 8 & 1.5 & 10 & Agreement \\
\hline 64 & $\begin{array}{l}\text { Most patients will benefit from treatment with AIT to slow disease } \\
\text { progression }\end{array}$ & 7.75 & 8 & 2 & 15 & Agreement \\
\hline 65 & $\begin{array}{l}\text { Most patients with ARD will benefit from treatment with AIT to } \\
\text { reduce the severity of symptoms and use of medication and to } \\
\text { improve quality of life }\end{array}$ & 7.95 & 8 & 1.5 & 7.5 & Agreement \\
\hline 66 & $\begin{array}{l}\text { Unlike pharmacological treatment, AIT improves the prognosis of } \\
\text { ARD }\end{array}$ & 8.08 & 8 & 1 & 5 & Agreement \\
\hline 67 & AIT decreases the occurrence of new sensitizations in ARD patients & 6.53 & 7 & 3 & 37.5 & No consensus \\
\hline 68 & $\begin{array}{l}\text { AIT can prevent the development of bronchial symptoms in patients } \\
\text { with rhinoconjunctivitis }\end{array}$ & 7.85 & 8 & 2 & 10 & Agreement \\
\hline 69 & $\begin{array}{l}\text { In ARD patients, identification of the airborne allergen that is clini- } \\
\text { cally responsible for symptoms is essential when attempting to } \\
\text { establish the indication of AIT }\end{array}$ & 8.7 & 9 & 0.5 & 0 & Agreement \\
\hline 70 & $\begin{array}{l}\text { The composition of immunotherapy in polysensitized ARD patients } \\
\text { must be based on a selection of the relevant allergen(s) according } \\
\text { to the patient's clinical and sensitization profile }\end{array}$ & 8.3 & 9 & 1 & 2.5 & Agreement \\
\hline 71 & $\begin{array}{l}\text { A sufficient dose of each allergen must be ensured in AIT with mix- } \\
\text { tures of allergens in polysensitized ARD patients }\end{array}$ & 8.23 & 8.5 & 1 & 5 & Agreement \\
\hline
\end{tabular}

Treatment-avoidance, drug treatment and allergen immunotherapy (AIT)

$A R D$ allergic respiratory disease, AIT allergen immunotherapy

"Unlike pharmacological treatment, AIT improves the prognosis of ARD" (item 66), mostly in monosensitized patients and when an adequate immune response is observed [32]. There is sufficient evidence to support the observation that "most patients with ARD will benefit from treatment with AIT to reduce the severity of symptoms and the use of medication and to improve quality of life" (item 65) [33-35]. Likewise, substantial evidence indicates a preventive effect in the progression from allergic rhinitis to asthma [36] (item 68), especially in children [37].

Some of the authors on the panel agreed that "AIT decreases the occurrence of new sensitizations in ARD patients" (item 67 ) $[38,39]$, although consensus was not 
reached. The experts considered that only some studies in children treated with pollen AIT have demonstrated the development of fewer new sensitizations when compared with those not treated with AIT. Furthermore, this has not been demonstrated for every allergen or in adults treated with AIT.

Polysensitization is an important factor when determining the prognosis of ARD and the indication for AIT (item 70). In polysensitized patients, both maintenance treatment strategies (item 61) and AIT composition (item 69) must be tailored after taking into consideration the most clinically relevant allergen. Therefore, AIT has proven to alleviate patients' overall symptoms owing to its effect on reducing the most relevant allergen-related symptoms [40].

However, polysensitization does not necessarily mean polyallergy [41]. Molecular diagnosis and knowledge of the predominant allergen are very useful for selecting genuinely polyallergic patients to receive AIT. It has been shown that the final composition of the AIT prescribed may need to be modified in up to $50 \%$ of patients when molecular diagnosis is used instead of the classic approach [42].

The inclusion of more than 1 allergen in AIT must be considered when there is more than 1 relevant allergen. The authors of this consensus advocate administration of the complete doses of each allergen to ensure the effectiveness of AIT, although this issue warrants further research (item 71).

\section{Classification of patients with ARD}

ARD is not reflected in the main clinical practice guidelines. Consequently, given that allergy is the most important cause of persistent rhinoconjunctivitis and asthma, the absence of specific references to patients with ARD [9] is remarkable. It is also interesting that the defining characteristics of ARD, such as the clinical variability conditioned by allergen exposure, have not been assessed. Therefore it is difficult to classify ARD patients according to the criteria currently proposed by guidelines (item 36 ).

The difficulty in fitting patients diagnosed with ARD with the guidelines lies in the fact that "the current classification is based on the assessment of the intensity and frequency of symptoms of rhinoconjunctivitis and asthma separately and does not assess the specific aspects of the causative allergens" (item 37). However, the expert panel agreed that "besides the intensity and duration, the description of ARD symptoms should also consider other aspects such as the frequency of the episodes, seasonality, and recurrence of symptoms at certain times" (item 38). The assessment of these aspects would enable a better approach in ARD patients.
The dynamic nature of allergic diseases has previously been described [37]. Indeed, "the clinical manifestations of ARD may be variable at different times in the patient's life" (item 8), with variation in the preponderance of nasal over bronchial symptoms [43]. Therefore, appropriate control of these patients requires the evaluation of the whole airway, even though symptoms may not be present at a given time.

The panel of experts highlighted the existence of several unmet needs. 1) Patients diagnosed with ARD require a specific classification that gives prominence to the causative agent (item 39). 2) It is necessary to propose a classification for diagnosis and treatment of ARD that simultaneously takes into account the severity, control, and clinical characteristics of the airborne allergens involved (Item 40). 3) The development of diagnostic and therapeutic approaches that take allergen exposure and the patient's environment into account would be useful in daily clinical practice. Multiple allergens are frequently implicated in ARD, making it very difficult to identify the most important one. Furthermore, we must bear in mind the existence of other factors not related to the allergen that might contribute to the onset of symptoms. 4) Rhinitis and asthma are currently classified, treated, and evaluated using different guidelines. However, the expert panel recommends a holistic approach to ARD patients, taking into account the clinical expression of respiratory disease at different levels and including its severity and level of control after treatment (Figs. 1, 2). It would be desirable to use questionnaires on disease control [44] and quality of life [45] to provide a global evaluation of ARD.

\section{Conclusions}

Despite the almost unanimous acceptance of the "one airway, one disease" concept, the current consensus guidelines apply two different standards for the management of patients with ARD. As far as we know, no one has previously addressed the need for a global approach to ARD. Therefore, the expert panel proposes a series of recommendations based on the specific aspects of allergic patients with rhinitis and asthma that can be useful in daily clinical practice (Table 7).

ARD patients are characterized by the presence of allergic rhinoconjunctivitis and/or asthma. The most suitable approach to these patients involves the assessment of all clinical manifestations of the disease, including both rhinoconjunctivitis and asthma, irrespective of whether they are present at a given time.

The clinical manifestations of ARD are variable and related to allergen exposure. Different airborne allergens can be related to specific clinical profiles in patients with 


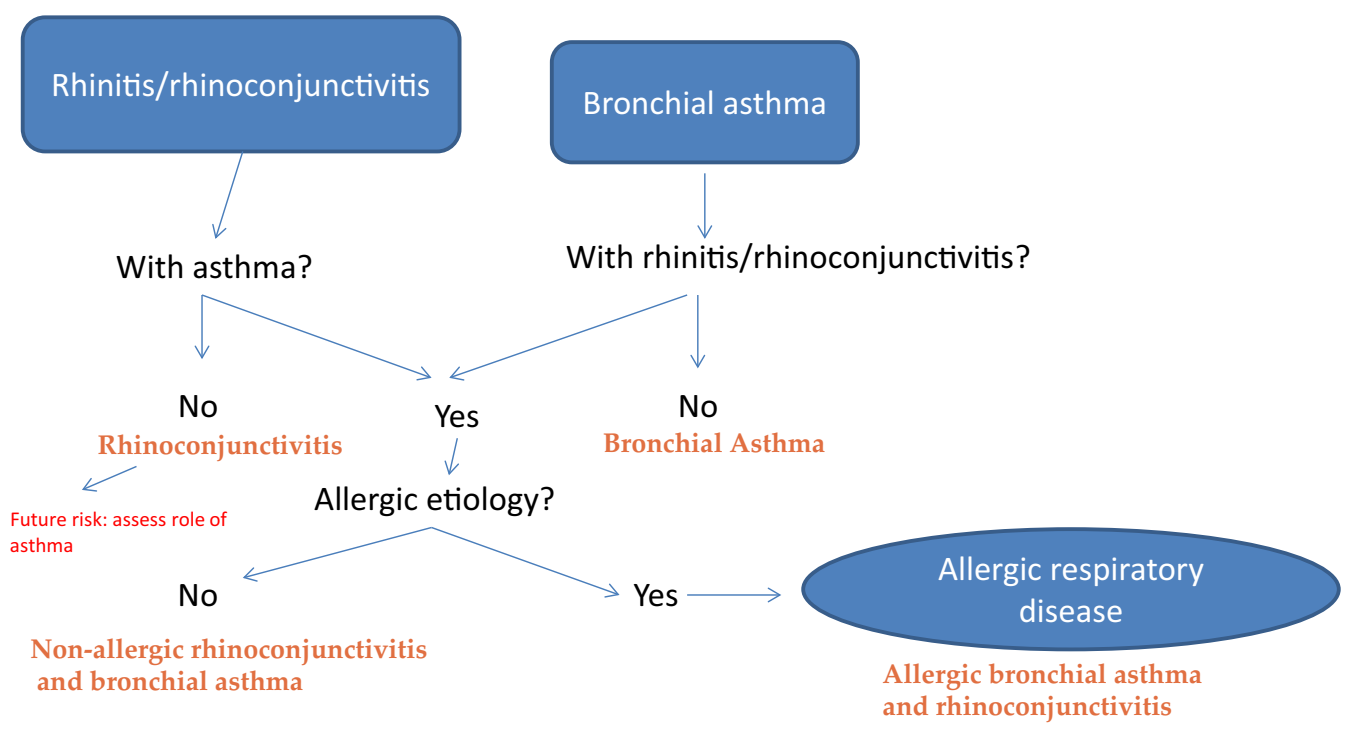

Fig. 1 Flow chart for diagnosis of allergic respiratory disease

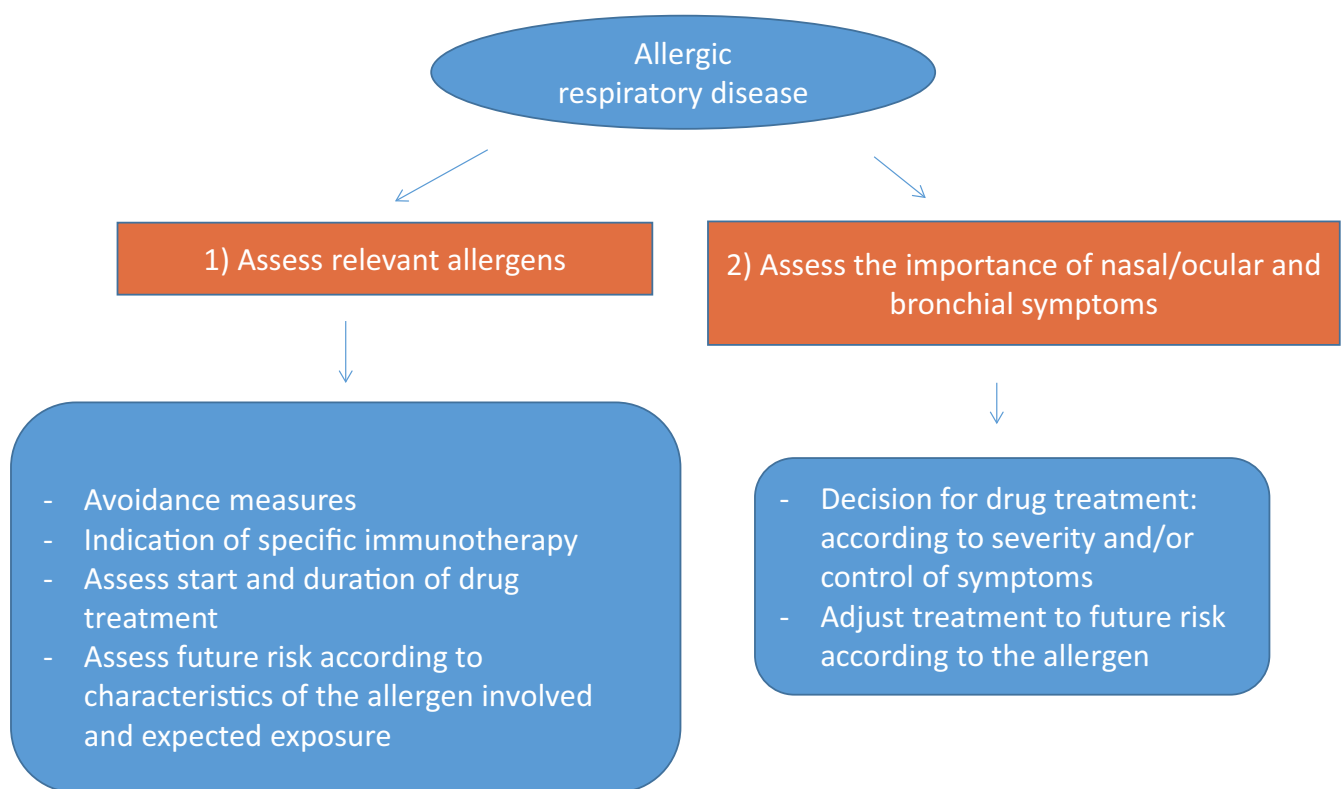

Fig. 2 Flow chart for treatment of allergic respiratory disease

ARD. Thus, the causative allergen must play a greater role in decisions on diagnosis and therapy, since the duration and severity of the disease are determined to a large extent by the allergen.

Pharmacological treatment is often chosen based on the severity of symptoms reached in previous allergenic exposures. Treatment with AIT is a comprehensive and etiological approach to the "one airway" disease. Therefore, AIT must be considered a first-line treatment and indicated in the early phases because, unlike pharmacological treatment, it can modify the prognosis of the disease.

\section{Unmet needs}

The peculiarities of ARD are not adequately reflected in the classifications of rhinitis and/or asthma proposed in current guidelines. Therefore, the expert panel considers the development of guidelines that recommend a comprehensive approach to patients with respiratory allergy to be an unmet need. 


\section{Table 7 Allergic respiratory disease (ARD): key points}

Allergic respiratory disease (ARD) includes patients with clinical manifestations of rhinoconjunctivitis and/or bronchial asthma of allergic etiology The optimal approach to ARD involves the simultaneous assessment of the upper and lower respiratory tract, irrespective of whether there are symptoms at a given time in a given patient

The clinical features of patients with ARD depend (in part) on the allergen that caused the symptoms and the characteristics of the exposure

The causative allergens of ARD must play a greater role in the choice of treatment

Decisions on drug treatment in patients with ARD may be affected by the clinical severity of previous allergen exposures and not follow the phased strategy suggested by guidelines

Allergen immunotherapy is a comprehensive etiological approach that can modify ARD. Failure of drug therapy is not a prerequisite for allergen immunotherapy in ARD patients

\section{Abbreviations}

ARD: allergic respiratory disease; AIT: allergen immunotherapy; SEAIC: Spanish Society of Allergology and Clinical Immunology.

\section{Authors' information}

All authors took part in the study as members of Asthma and Rhinoconjunctivitis Committees of the Spanish Society of Allergology and Clinical Immunology (SEAIC)

\section{Author details}

${ }^{1}$ UGC of Allergy, Hospital El Tomillar, Carretera Alcalá - Dos Hermanas km 6, 41700 Dos Hermanas, Seville, Spain. ${ }^{2}$ UGC of Allergy, Hospital Universitario Virgen Macarena, Seville, Spain. ${ }^{3}$ Allergy Unit, Pneumology Department, Hospital Clinic, Institut d'Investigacions Biomèdiques August Pi Sunyer (IDIBAPS), Barcelona, Spain. ${ }^{4}$ Allergy Service, Hospital Municipal, Badalona Serveis Assistencials, Badalona, Spain. ${ }^{5}$ Allergy Service, Sant Pere Claver Fundació Sanitària, Barcelona, Spain. ${ }^{6}$ Department of Allergy, Hospital La Paz Institute for Health Research (IdiPAZ), Madrid, Spain.

\section{Authors' contributions}

AN, JD, RM, TD, AV, and SQ designed the study, reviewed the medical literature on the topic, and discussed the main items to be included in the structured questionnaire. All of the members of the Asthma and Rhinoconjunctivitis Committees SEAIC 2010-2014 took part in the study. AN, JD, RM, TD, AV, and SQ analyzed the results, discussed the main conclusions, and drafted the manuscript. All authors read and approved the final manuscript.

\section{Acknowledgements}

ARD Study Group: M José Álvarez, Complejo Hospitalario de Navarra, Pamplona; Encarnación Antón, Hospital Universitario Marqués de Valdecilla, Santander; Pilar Barranco, Hospital La Paz, Madrid; Paloma Campo, Hospital Regional Universitario, Málaga; Remedios Cárdenas, Hospital Universitario de Guadalajara; Carlos Colás, Hospital Clínico Universitario, Instituto de Investigación Sanitaria de Aragón, Zaragoza; Ignacio Dávila, Hospital Universitario, IBSAL Departamento de Ciencias Biomédicas y del Diagnóstico, Salamanca; Alfonso del Cuvillo, Hospital de Especialidades de Jerez, Cádiz; Javier Domínguez-Ortega, Hospital La Paz, Madrid; Beatriz Fernández, Hospital El Bierzo, Ponferrada, León; M José Giménez, Área Vigilancia de La Salud CPRL, Málaga; Elisa Gómez, Hospital General Universitario de Ciudad Real; M Luisa González, Hospital Clínico San Carlos, Madrid; Ruperto González, Hospital Universitario Nuestra Señora de Candelaria, Tenerife; Valentina Gutiérrez, Hospital Dr. Peset, Valencia; F. Javier Iglesias-Souto, Hospital Universitario Nuestra Señora de Candelaria, Tenerife; Magdalena Lluch, Hospital La Paz, Madrid; M Aránzazu Martín, Hospital Santa Bárbara de Puertollano, Ciudad Real; Víctor Matheu, Hospital Universitario Nuestra Señora de Candelaria, Tenerife; Javier Montoro, Hospital Arnau de Vilanova, Valencia; José M Olaguibel, Complejo Hospitalario de Navarra; M Carmen Panizo, Hospital Nuestra Señora del Prado, Toledo; Antonio Parra, Complexo Hospitalario Universitario A Coruña; M José Pascual, Centro de Alergia y Asma Balear, Palma de Mallorca; Carmen Pérez, Hospital Dr. Peset, Valencia; Fernando Rodríguez, Hospital Universitario Marqués de Valdecilla, Santander; Mercedes Rodríguez, Hospital Universitario Príncipe de Asturias, Alcalá de Henares, Madrid; Carmen Rondón, Hospital
Regional Universitario, Málaga; M Cesárea Sánchez, Hospital Juan Ramón Jiménez, Huelva; Silvia Sánchez-García, Hospital Infantil Universitario Niño Jesús, Madrid; Joaquín Sastre, Hospital Universitario Fundación Jiménez Díaz, Madrid; Francisco Vega, Hospital de la Princesa, Madrid; Jose M Vega, Hospital Regional Universitario, Málaga; M Esther Velázquez; Hospital Quirón Sagrado Corazón, Sevilla. The authors thank Laboratorios LETI SLU (Spain) for logistic support for in the Delphi meetings and SEAIC by its endorsed.

\section{Competing interests}

All of the authors took part in the study as members of the Asthma and Rhinoconjunctivitis Committees of the Spanish Society of Allergology and Clinical Immunology (SEAIC). This study was endorsed by SEAIC. The authors declare that they have no competing interests.

\section{Availability of data and materials}

All data generated or analyzed during this study are included in the present manuscript.

\section{Publisher's Note}

Springer Nature remains neutral with regard to jurisdictional claims in published maps and institutional affiliations.

Received: 21 February 2017 Accepted: 3 May 2017

Published online: 18 May 2017

\section{References}

1. Bousquet J, Van Cauwenberge P, Khaltaev N, Aria Workshop Group, World Health Organization. Allergic rhinitis and its impact on asthma. J Allergy Clin Immunol. 2001;108(Suppl 5):147-334.

2. Bousquet J, Khaltaev N, Cruz AA, Denburg J, Fokkens WJ, Togias A, et al. Allergic Rhinitis and its Impact on Asthma (ARIA) 2008 update (in collaboration with the World Health Organization, GA(2)LEN and AllerGen). Allergy. 2008;63(Suppl 86):8-160.

3. Scadding GK, Durham SR, Mirakian R, Jones NS, Leech SC, Farooque S, et al. BSACI guidelines for the management of allergic and non-allergic rhinitis. Clin Exp Allergy. 2008;38:19-42.

4. Wallace DV, Dykewicz MS, Bernstein DI, Blessing-Moore J, Cox L, Khan DA, et al. The diagnosis and management of rhinitis: an updated practice parameter. J Allergy Clin Immunol. 2008;122(Suppl 2):1-84.

5. Brozek JL, Bousquet J, Baena-Cagnani CE, Bonini S, Canonica GW, Casale TB, et al. Allergic Rhinitis and its Impact on Asthma (ARIA) guidelines: 2010 revision. J Allergy Clin Immunol. 2010;126:466-76.

6. Seidman MD, Gurgel RK, Lin SY, Schwartz SR, Baroody FM, Bonner JR, et al. Clinical practice guideline: allergic rhinitis. Otolaryngol Head Neck Surg. 2015;152(Suppl 1):S1-43.

7. Plaza V, Alonso S, Alvarez C, Gomez-Outes A, Gómez F, López A, et al. Spanish Guideline on the Management of Asthma. J Investig Allergol Clin Immunol. 2016;26(Suppl 1):S1-92.

8. 2016 GINA Report, Global Strategy for Asthma Management and Prevention. http://www.ginasthma.org. Accessed 23 Jan 2016. 
9. British Thoracic Society; Scottish Intercollegiate Guidelines Network. British guideline on the Management of Asthma. Thorax. 2014;69(Suppl 1):1-192. https://www.brit-thoracic.org.uk/document-library/clinicalinformation/asthma/btssign-asthma-guideline-2014/. Accessed 23 Jan 2016

10. National Asthma Education and Prevention Program. Expert panel report 3 (EPR-3): guidelines for the Diagnosis and Management of Asthma-Summary Report 2007. J Allergy Clin Immunol. 2007;120(Suppl 5):S94-138

11. Paul CL. A modified Delphi approach to a new card sorting methodology. J Usability Stud. 2008; 4:7-30. http://uxpajournal.org/a-modified-delphiapproach-to-a-new-cardsorting-methodology/ Accessed 23 Jan 2016

12. Holey EA, Feeley JL, Dixon J, Whittaker VJ. An exploration of the use of simple statistics to measure consensus and stability in Delphi studies. BMC Med Res Methodol. 2007;7:52.

13. Grossman J. One airway, one disease. Chest. 1997;111:11-6.

14. Braunsthal GJ, Kleinjan A, Overbeek SE, Prins JB, Hoogsteden HC, Fokkens WJ. Segmental bronchial provocation induces nasal inflammation in allergic rhinitis patients. Am J Respir Crit Care Med. 2000;161:2051-7.

15. Panzner P, Malkusová I, Vachová M, Liška M, Brodská P, Rủžičková O, et al. Bronchial inflammation in seasonal allergic rhinitis with or without asthma in relation to natural exposure to pollen allergens. Allergol Immunopathol (Madr). 2015;43:3-9.

16. Bousquet J, Vignola AM, Demoly P. Links between rhinitis and asthma. Allergy. 2003;58:691-706.

17. Domínguez-Ortega J, Quirce S, Delgado J, Dávila I, Martí-Guadaño E, Valero A. Diagnostic and therapeutic approaches in respiratory allergy are different depending on the profile of aeroallergen sensitisation. Allergol Immunopathol (Madr). 2014:42:11-8.

18. Li J, Huang Y, Lin X, Zhao D, Tan G, Wu J, et al. China alliance of research on respiratory allergic disease (CARRAD). Influence of degree of specific allergic sensitivity on severity of rhinitis and asthma in Chinese allergic patients. Respir Res. 2011;12:95.

19. Ramirez DA. The natural history of mountain cedar pollinosis. J Allergy Clin Immunol. 1984;73:88-93.

20. Knutsen AP, Bush RK, Demain JG, Denning DW, Dixit A, Fairs A, et al. Fungi and allergic lower respiratory tract diseases. J Allergy Clin Immunol. 2012;129:280-91.

21. Kidon MI, Chiang WC, Liew WK, Ong TC, Tiong YS, Wong KN, et al. Mite component-specific lgE repertoire and phenotypes of allergic disease in childhood: the tropical perspective. Pediatr Allergy Immunol. 2011:22:202-10.

22. Delgado J, Dávila I, Domínguez-Ortega J, Quirce S, Martí-Guadaño E, Valero A. Quality of life in patients with respiratory allergy is influenced by the causative allergen. J Investig Allergol Clin Immunol. 2013;23:309-14.

23. Warm K, Hedman L, Lindberg A, Lötvall J, Lundbäck B, Rönmark E. Allergic sensitization is age-dependently associated with rhinitis, but less so with asthma. J Allergy Clin Immunol. 2005;136:1559-65.

24. ten Brinke A, Sterk PJ, Masclee AA, Spinhoven P, Schmidt JT, Zwinderman $\mathrm{AH}$, et al. Risk factors of frequent exacerbations in difficult-to-treat asthma. Eur Respir J. 2005:26:812-8.

25. Twaroch TE, Curin M, Valenta R, Swoboda I. Mold allergens in respiratory allergy: from structure to therapy. Allergy Asthma Immunol Res. 2015;7:205-20.

26. Boulet LP, Gauvreau G, Boulay ME, O'Byrne PM, Cockcrof DW. Allergeninduced early and late asthmatic responses to inhaled seasonal and perennial allergens. Clin Exp Allergy. 2015:45:1647-53.

27. Murray CS, Poletti G, Kebadze T, Morris J, Woodcock A, Johnston SL, et al. Study of modifiable risk factors for asthma exacerbations: virus infection and allergen exposure increase the risk of asthma hospital admissions in children. Thorax. 2006;61:376-82.
28. Froidure A, Vandenplas O, D'Alpaos V, Evrard G, Pilette C. Persistence of asthma following allergen avoidance is associated with proTh2 myeloid dendritic cell activation. Thorax. 2015;70:967-73.

29. Canova C, Heinrich J, Anto JM, Leynaert B, Smith M, Kuenzli N, et al. The influence of sensitisation to pollens and moulds on seasonal variations in asthma attacks. Eur Respir J. 2013;42:935-45.

30. Calderón MA, Linneberg A, Kleine-Tebbe J, De Bley F, Fernandez Hernandez, de Rojas D, Virchow JC, et al. Respiratory allergy caused by house dust mites: what do we really know? J Allergy Clin Immunol. 2015;136:38-48.

31. Canonica GW, Cox L, Pawankar R, Baena-Cagnani CE, Blaiss M, Bonini S, et al. Sublingual immunotherapy: world Allergy Organization position paper 2013 update. World Allergy Organ J. 2014;7:6.

32. Jutel M, Agache I, Bonini S, Burks AW, Calderon M, Canonica W, et al. International consensus on allergy immunotherapy. J Allergy Clin Immunol. 2015:136:556-68.

33. Lin SY, Erekosima N, Kim JM, Ramanathan M, Suarez-Cuervo C, Chelladurai $Y$, et al. Sublingual immunotherapy for the treatment of allergic rhinoconjunctivitis and asthma: a systematic review. JAMA. 2013;309:1278-88.

34. Erekosima N, Suarez-Cuervo C, Ramanathan M, Kim JM, Chelladurai Y, Segal JB, et al. Effectiveness of subcutaneous immunotherapy for allergic rhinoconjunctivitis and asthma: a systematic review. Laryngoscope. 2014;124:616-27.

35. Kim JM, Lin SY, Suarez-Cuervo C, Chelladurai Y, Ramanathan M, Segal JB, et al. Allergen-specific immunotherapy for pediatric asthma and rhinoconjunctivitis: a systematic review. Pediatrics. 2013;131:1155-67.

36. Cardona V, Luengo O, Labrador-Horrillo M. Immunotherapy in allergic rhinitis and lower airway outcomes. Allergy. 2017;72:35-42.

37. Morjaria JB, Caruso M, Rosalia E, Russo C, Polosa R. Preventing progression of allergic rhinitis to asthma. Curr Allergy Asthma Rep. 2014;14:412.

38. Eng PA, Borer-Reinhold M, Heijnen IA, Gnehm HP. Twelve-year follow-up after discontinuation of preseasonal grass pollen immunotherapy in childhood. Allergy. 2006;61:198-201.

39. Burks AW, Calderon MA, Casale T, Cox L, Demoly P, Jutel M, et al. Update on allergy immunotherapy: American Academy of Allergy, Asthma \& Immunology/European Academy of Allergy and Clinical Immunology/ PRACTALL consensus report. J Allergy Clin Immunol. 2013;131:1288-96.

40. Bahceciler NN, Galip N, Cobanoglu N. Multiallergen-specific immunotherapy in polysensitized patients: where are we? Immunotherapy. 2013:5:183-90.

41. Migueres M, Dávila I, Frati F, Azpeitia A, Jeanpetit Y, Lhéritier-Barrand M, Incorvaia C, Ciprandi G, PlurAL study group. Types of sensitization to aeroallergens: definitions, prevalences and impact on the diagnosis and treatment of allergic respiratory disease. Clin Transl Allergy. 2014:4:16.

42. Sastre J, Landivar ME, Ruiz-García M, Andregnette-Rosigno MV, Mahillo I. How molecular diagnosis can change allergen-specific immunotherapy prescription in a complex pollen area. Allergy. 2012;67:709-11.

43. Cruz AA. The 'united airways' require an holistic approach to management. Allergy. 2005;60:871-4.

44. Fonseca JA, Nogueira-Silva L, Morais-Almeida M, Sa-Sousa A, Azevedo LF, Ferreira J, et al. Control of Allergic Rhinitis and Asthma Test (CARAT) can be used to assess individual patients over time. Clin Transl Allergy. 2012:2:16.

45. Braido F, Baiardini I, Stagi E, Scichilone N, Rossi O, Lombardi C, et al. RhinAsthma patient perspective: a short daily asthma and rhinitis $\mathrm{QoL}$ assessment. Allergy. 2012;67:1443-50. 